\title{
IGFBP-rP1-silencing promotes hypoxia-induced angiogenic potential of choroidal endothelial cells via the RAF/MEK/ERK signaling pathway
}

\author{
SHUTING ZHU ${ }^{1,2^{*}}$, HONG WANG ${ }^{1-5^{*}}$, ZHIHUA ZHANG $^{1-5}$, MINGMING MA $^{1-5}$, \\ ZHI ZHENG ${ }^{1-5}, \mathrm{XUN}_{\mathrm{XU}}{ }^{1-5}$ and TAO SUN ${ }^{1-5}$ \\ ${ }^{1}$ Department of Ophthalmology; ${ }^{2}$ Shanghai Key Laboratory of Ocular Fundus Diseases; \\ ${ }^{3}$ National Clinical Research Center for Eye Diseases; ${ }^{4}$ Shanghai Engineering Center for Visual Science and Photomedicine; \\ ${ }^{5}$ Shanghai Engineering Center for Precise Diagnosis and Treatment of Eye Diseases, School of Medicine, \\ Shanghai General Hospital, Shanghai Jiao Tong University, Shanghai 200080, P.R. China
}

Received February 15, 2020; Accepted August 25, 2020

DOI: $10.3892 / \mathrm{mmr} .2020 .11578$

\begin{abstract}
Insulin-like growth factor binding protein-related protein 1 (IGFBP-rP1) has been reported to have various functions in different cellular contexts. Our previous investigation discovered that IGFBP-rP1 inhibited retinal angiogenesis in vitro and in vivo by inhibiting the pro-angiogenic effect of VEGF and downregulating VEGF expression. Recently, IGFBP-rP1 was confirmed to be downregulated in the aqueous humor of patients with neovascular age-related macular degeneration compared with controls; however, its specific role remains unknown. The present study applied the technique of gene silencing, reverse transcription-quantitative PCR, western blotting, cell viability assays, cell motility assays and tube formation assays. Chemical hypoxic conditions and choroidal endothelial (RF/6A) cells were used to explore the effect of IGFBP-rP1-silencing on the phenotype activation of RF/6A cells under hypoxic conditions and to elucidate the underlying mechanisms. siRNA achieved IGFBP-rP1-silencing in RF/6A cells without cytotoxicity. IGFBP-rP1-silencing significantly restored the viability of RF/6A cells in hypoxia and enhanced hypoxia-induced migration and capillary-like tube formation
\end{abstract}

Correspondence to: Dr Tao Sun, Department of Ophthalmology, School of Medicine, Shanghai General Hospital, Shanghai Jiao Tong University, 100 Haining Road, Shanghai 200080, P.R. China

E-mail: drsuntao@yeah.net

*Contributed equally

Abbreviations: IGFBP-rP1, insulin-like growth factor binding protein-related protein 1; siIGFBP-rP1, IGFBP-rP1 specific siRNA; AMD, age-related macular degeneration; $\mathrm{CNV}$, choroidal neovascularization

Key words: insulin-like growth factor binding protein-related protein 1, RAF/MEK/ERK signaling pathway, vascular endothelial growth factor, choroidal endothelial cells, hypoxia, angiogenesis of RF/6A cells. Furthermore, IGFBP-rP1-silencing significantly upregulated the expression of B-RAF, phosphorylated (p)-MEK, p-ERK and VEGF in RF/6A cells under hypoxic conditions; however, these upregulations were inhibited by exogenous IGFBP-rP1. These data indicated that silencing IGFBP-rP1 expression in RF/6A cells effectively promoted the hypoxia-induced angiogenic potential of choroidal endothelial cells by upregulating RAF/MEK/ERK signaling pathway activation and VEGF expression.

\section{Introduction}

Angiogenesis, a process of novel blood vessel formation from the pre-existing vasculature, serves a critical role in numerous human neovascularization diseases, such as diabetic retinopathy, ischemia/reperfusion injury and carcinogenesis (1). Vascular homeostasis is an intrinsically regulated procedure controlled by the balance of angiogenic and anti-angiogenic factors during normal physiological activities (1). Once homeostasis is interrupted, neovascularization is inevitable, becoming a major cause of irreversible vision loss in various clinical eye diseases, including retinopathy of prematurity, diabetic retinopathy and age-related macular degeneration (AMD) (2-4).

The underlying molecular mechanisms of choroidal neovascularization (CNV) are multifactorial and complicated. Previous studies have demonstrated that hypoxia and ischemia serve important roles in the formation of CNV (5-8). Multiple hypoxia-induced growth factors and inflammatory cytokines, including VEGF, hypoxia-inducible factor- $1 \alpha$, TNF- $\alpha$ and IL-1, stimulated the progression of CNV (5-8). Among these factors, VEGF is hypothesized to be the most important inducer of CNV under hypoxic conditions (5-9).

Insulin-like growth factor binding protein-related protein 1 (IGFBP-rP1) is a soluble-secreted 36-kDa glycoprotein, also known as IGFBP7, mac25, TAF and angiomodulin $(10,11)$. IGFBP-rP1 is distinct from other IGFBPs since it exhibits a low affinity for IGFs and a high affinity for insulin $(10,11)$. Our previous studies have revealed that IGFBP-rP1 suppressed 
the phenotype activation of retinal endothelial cells induced by VEGF in vitro and inhibited retinal angiogenesis by downregulating VEGF in vivo $(12,13)$. Notably, IGFBP-rP1 was demonstrated to be decreased in the aqueous humor of patients with CNV secondary to AMD compared with control patients with cataract; however, its specific role remains unknown (14).

In the present study, IGFBP-rP1 specific small interfering RNA (siIGFBP-rP1) was transfected into choroidal endothelial $(\mathrm{RF} / 6 \mathrm{~A})$ cells to block the expression of IGFBP-rP1 under hypoxic conditions to investigate the role of IGFBP-rP1-silencing in the hypoxia-induced angiogenic potential of choroidal endothelial cells and the underlying mechanisms.

\section{Materials and methods}

Media and reagents. Lipofectamine ${ }^{\circledR} 3000$ transfection reagent was purchased from Thermo Fisher Scientific, Inc. PrimeScript reverse transcription (RT) reagent kit and SYBR Premix Ex Taq Real-Time PCR kit were purchased from Takara Bio, Inc. and were used in RT-quantitative (q)PCR assays. Recombinant human IGFBP-rP1 and goat anti-human IGFBP-rP1 polyclonal antibody (cat. no. AF1334) were obtained from R\&D Systems, Inc. Rabbit anti-human GAPDH polyclonal (cat. no. 10494-1-AP) and mouse anti-human $\beta$-actin monoclonal (cat. no. 66009-1-Ig) antibodies were obtained from ProteinTech Group, Inc. Rabbit anti-human VEGF polyclonal (cat. no. ab150766) antibodies were purchased from Abcam. The other primary antibodies, including rabbit anti-human B-RAF monoclonal (cat. no. 14814), rabbit anti-human phosphorylated-MEK (p-MEK) polyclonal (cat. no. 9121), rabbit anti-human MEK polyclonal (cat. no. 9122), rabbit anti-human phosphorylated-ERK (p-ERK) polyclonal (cat. no. 9101) and rabbit anti-human ERK polyclonal (cat. no. 9102) antibodies were purchased from Cell Signaling Technology, Inc. Horseradish peroxidase (HRP) mouse anti-goat (cat. no. sc2354), goat anti-rabbit (cat. no. sc-2004) and goat anti-mouse (cat. no. sc-2005) secondary antibodies were obtained from Santa Cruz Biotechnology, Inc. The PVDF membranes and Chemiluminescent HRP Substrate reagent were purchased from EMD Millipore. CellTiter 96 ${ }^{\circledR}$ AQueous One Solution Cell Proliferation Assay (MTS Assay) was purchased from Promega Corporation. Transwell Permeable Supports with an $8-\mu$ m pore polycarbonate filter were purchased from Corning, Inc. Growth factor-reduced Matrigel matrix was purchased from BD Biosciences. All other chemicals were of reagent grade and obtained from Merck KGaA, unless otherwise specified.

Cell line and culture. RF/6A cells, a well-established choroid endothelial cell line for studying CNV pathogenesis (15-17), were obtained from the Cell Bank of the Chinese Academy of Sciences. The cells were cultured in RPMI-1640 medium (Thermo Fisher Scientific, Inc.) supplemented with 10\% FBS (Thermo Fisher Scientific, Inc.) and 1\% penicillin/streptomycin (GE Healthcare Life Sciences). The cells were maintained at $37^{\circ} \mathrm{C}$ in a $5 \% \mathrm{CO}_{2}$-humidified incubator and the medium was changed every 2 or 3 days. Prior to experimental intervention, the medium was replaced with serum-free RPMI-1640 for $12 \mathrm{~h}$.
Following siRNA transfection for $24 \mathrm{~h}, \mathrm{RF} / 6 \mathrm{~A}$ cells were subjected to hypoxic conditions and IGFBP-rP1-restored conditions for further study. Cobalt chloride $\left(\mathrm{CoCl}_{2}\right.$; Merck $\mathrm{KGaA}$ ) at a final concentration of $200 \mu \mathrm{mol} / 1$ or $1 \% \mathrm{O}_{2}$ in the presence of $5 \% \mathrm{CO}_{2}$ and $94 \% \mathrm{~N}_{2}$ using a ProOx C21 System (BioSpherix, Ltd.) was used to mimic hypoxic conditions. To restore IGFBP-rP1 expression, recombinant human IGFBP-rP1 was added at a final concentration of $200 \mathrm{ng} / \mathrm{ml}$ for $24 \mathrm{~h}$ in the conditions of the siIGFBP-rP1 duplex 2 group, which has been demonstrated by previous studies (18-20). All experiments were performed in triplicate.

IGFBP-rPl gene silencing. siRNAs for IGFBP-rP1 were purchased from Guangzhou RiboBio Co., Ltd. The sequences of the positive siIGFBP-rP1 duplex 1 and 2 were 5'-TCC-TCC-TCT-TCG-GAC-ACC-T-3' and 5'-GTC-GCTACA-TGC-CCT-GCT-C-3', respectively. RF/6A cells were seeded into six-well plates and transfected with $50 \mathrm{nM}$ siRNA using Lipofectamine ${ }^{\circledR} 3000$ transfection reagent. Briefly, $50 \mathrm{nM}$ siRNA in Opti-MEM medium (Thermo Fisher Scientific, Inc.) was mixed with $4 \mu 1$ Lipofectamine ${ }^{\circledR} 3000$ and incubated for $25 \mathrm{~min}$ at room temperature prior to adding the mixture to the cells cultured in serum-free medium. The cells were incubated at $37^{\circ} \mathrm{C}$ for $5 \mathrm{~h}$. Following this, the medium was replaced with RPMI-1640 complete medium for $48 \mathrm{~h}$ before the level of silencing was determined by RT-qPCR and western blotting. Scramble control siRNA, transfection reagent and blank control were used to compare the effects of siIGFBP-rP1.

$R N A$ extraction and $R T-q P C R$. Total RNA was extracted from cultured RF/6A cells using a RNeasy Mini kit (Qiagen, Inc.), according to the manufacturer's protocol. Total RNA was eluted in $40 \mu \mathrm{l}$ nuclease-free water. The concentration and purity of RNA were measured by spectrophotometry (NanoDrop 8000; Thermo Fisher Scientific, Inc.) at $15^{\circ} \mathrm{C}$ within $10 \mathrm{sec}$. In all RNA preparations, the ratio of optical density (OD) ${ }_{260}$ to 280 was 1.9:2.0. Equal amounts of RNA $(0.5 \mu \mathrm{g})$ were converted into cDNA using PrimeScript RT reagent kit (Takara Bio, Inc.) and qPCR was performed using SYBR Premix Ex Taq real-time PCR kit (Takara Bio, Inc.), according to the manufacturer's protocols. The primers of IGFBP-rP1 and GAPDH were designed and synthesized by Sangon Biotech Co., Ltd. GAPDH served as an internal reference for the control. The primer sequences used were as follows: IGFBP-rP1 forward, 5'-AGC-TGT-GAG-GTC-ATC-GGA-AT-3' and reverse, 5'-CAG-CAC-CCA-GCC-AGT-TAC-TT-3'; and GAPDH forward, 5'-GAG-TCA-ACG-GAT-TTG-GTC-GT-3' and reverse, 5'-GAC-AAG-CTT-CCC-GTT-CTC-AG-3'. The One-Step RT-PCR thermocycling conditions were as follows: 30 min of initial reverse transcription at $50^{\circ} \mathrm{C}$, enzyme heat-activation at $95^{\circ} \mathrm{C}$ for $15 \mathrm{~min}$, followed by 35 three-step amplification cycles of denaturation at $94^{\circ} \mathrm{C}$ for $40 \mathrm{sec}$, annealing at $60^{\circ} \mathrm{C}$ for $40 \mathrm{sec}$ and extension at $72^{\circ} \mathrm{C}$ for $1 \mathrm{~min}$. The qPCR thermocycling conditions were as follows: enzyme heat-activation at $95^{\circ} \mathrm{C}$ for $30 \mathrm{sec}$, followed by 40 two-step amplification cycles of denaturation at $95^{\circ} \mathrm{C}$ for $5 \mathrm{sec}$, annealing and extension at $60^{\circ} \mathrm{C}$ for $35 \mathrm{sec}$. Relative gene expression was calculated using a standard curve (the optical density was determined at $280 \mathrm{~nm}$ ) and IGFBP-rP1 mRNA levels were normalized to GAPDH. 
Western blotting. The RF/6A cells cultured in the IGFBP-rP1-silencing group, the hypoxic group and the control group were washed with phosphate-buffered saline (PBS) twice and lysed in ice-cold RIPA buffer $(1 \mathrm{mmol} / 1$ phenylmethyl sulfonylfluoride, $10 \mu \mathrm{g} / \mathrm{ml}$ leupeptin and $10 \mu \mathrm{g} / \mathrm{ml}$ aprotinin). Following $30 \mathrm{~min}$ on ice, lysates were scraped into microcentrifugation tubes and centrifuged at $14,000 \times \mathrm{g}$ for $10 \mathrm{~min}$ at $4^{\circ} \mathrm{C}$. The supernatant was removed and the protein concentrations were quantified using a Pierce protein assay kit (Pierce; Thermo Fisher Scientific, Inc.), according to the manufacturer's protocol. Cell lysates (30 $\mu \mathrm{g}$ protein/lane) were separated by $10 \%$ SDS-PAGE and transferred onto PVDF membranes. Following blocking with $5 \%$ blocking liquid diluted in Tris-buffered saline with $0.1 \%$ Tween-20 for $1 \mathrm{~h}$ at $37^{\circ} \mathrm{C}$, membranes were incubated with different dilutions of primary antibodies overnight at $4^{\circ} \mathrm{C}$. The following day, the membranes were washed three times and subsequently incubated with HRP-conjugated secondary antibodies for $1 \mathrm{~h}$ at room temperature. The primary antibodies used included IGFBP-rP1 (1:500), B-RAF (1:500), p-MEK (1:1,000), MEK $(1: 1,000)$, p-ERK $(1: 1,000)$, ERK $(1: 1,000)$, VEGF $(1: 1,000)$, GAPDH $(1: 1,000)$ and $\beta$-actin $(1: 1,000)$ antibodies. The dilution for the secondary antibodies was 1:5,000. Signals were detected by enhanced chemiluminescence (Western Lighting Plus-ECL; PerkinElmer, Inc.) and quantified by densitometry using Gel-Pro Analyzer software (version no. 4.0; Media Cybernetics, Inc.). GAPDH and $\beta$-actin were used as the internal controls.

Cell viability assay. Cell viability was evaluated by MTS colorimetric assays, as previously described (12). Briefly, cells were seeded in a 96-well plate $\left(100 \mu \mathrm{l} / \mathrm{well} ; 5 \times 10^{4}\right.$ cells $\left./ \mathrm{ml}\right)$ and allowed to attach overnight in the serum-free medium. Following this, cells were transfected with siRNA duplex 1 and 2 for $6,12,24,48$ and 72 h to plot growth curves The cells transfected with siRNA duplex 2 for $24 \mathrm{~h}$ were then exposed to $\mathrm{CoCl}_{2}$ mimetic and $1 \% \mathrm{O}_{2}$-induced hypoxia for 6 , $12,24,48$ and $72 \mathrm{~h}$ at $37^{\circ} \mathrm{C}$ in a $5 \% \mathrm{CO}_{2}$-humidified incubator to compare differences between these two types of hypoxic conditions on cell proliferation. Finally, MTS reagent $(20 \mu \mathrm{l})$ was added to each well for $2 \mathrm{~h}$ and the absorbance and OD values at $490 \mathrm{~nm}$ were recorded using a Wallac Victor 1420 plate reader (PerkinElmer, Inc.).

Cell motility assay. Wound and Transwell assays were performed to assess cell motility. Confluent monolayers of the transfected or untransfected cells $\left(4 \times 10^{5}\right.$ cells/well) in 6-multiwell plates were wounded using a pipette tip and washed with PBS three times. Following this, the plates were incubated in DMEM (1\% FBS) containing $200 \mu \mathrm{mol} / 1 \mathrm{CoCl}_{2}$ for $24 \mathrm{~h}$ at $37^{\circ} \mathrm{C}$ in a $5 \% \mathrm{CO}_{2}$ incubator. Images of the wounded area were immediately recorded at the time of wounding and at $24 \mathrm{~h}$ using an inverted microscope (IX50; Olympus Corporation) at a magnification of $x 400$. The relative migration area of cells that had migrated from the edge of the wound was calculated using ImageJ software (version 1.50; National Institutes of Health).

The Transwell assays was performed as previously described (12). Briefly, the transfected or untransfected cells were placed in the upper chamber $\left(6 \times 10^{4}\right.$ cells/chamber $)$ at a final volume of $100 \mu \mathrm{l}$ of the serum-free RPMI-1640 medium. Following this, the normal or $\mathrm{CoCl}_{2}$-induced hypoxic medium was placed in the bottom chamber at a final volume of $600 \mu \mathrm{l}$. Following incubation for $24 \mathrm{~h}$, the filters were fixed in $10 \%$ paraformaldehyde for $20 \mathrm{~min}$ at room temperature and stained with hematoxylin for $15 \mathrm{~min}$ at room temperature. Cells on the lower surface of the filters were counted in five randomly selected fields/filter under a light microscope (BX50; Olympus Corporation) at a magnification of $\mathrm{x} 200$.

Tube formation assay. Tube formation assays were performed by placing ice-cold growth factor-reduced Matrigel matrix in a prechilled 96 -well plate $(50 \mu \mathrm{l} /$ well), followed by incubation at $37^{\circ} \mathrm{C}$ for $30 \mathrm{~min}$ to allow polymerization. Next, siIGFBP-rP1 transfected cells $\left(8 \times 10^{4}\right.$ cells/well $)$ were seeded on the Matrigel-coated 96-well plate and incubated for $24 \mathrm{~h}$ under normal or hypoxic conditions. Enclosed capillary-like tube structures within the Matrigel layer from five randomly selected fields/well were captured under an inverted phase contrast microscope (BX40; Olympus Corporation) at a magnification of $x 50$. The tube length was measured by Image-Pro Plus Analyzer software (version no. 6.0; Media Cybernetics, Inc.).

Statistical analysis. A one-way ANOVA followed by Dunnett's post-hoc test was used to evaluate differences between the control and intervention groups assessed by different experiments. All tests were performed using SPSS for Windows (version no. 13.0; SPSS Inc.). Data are presented as the mean + standard deviation. $\mathrm{P}<0.05$ was considered to indicate a statistically significant difference.

\section{Results}

IGFBP-rPl-silencing in RF/6A cells by siRNA does not exhibit cytotoxicity. Two different siRNA sequences were designed for transfection to attain a higher knockdown efficiency. Firstly, the expression of IGFBP-rP1 was confirmed in $\mathrm{RF} / 6 \mathrm{~A}$ cells without the specific siRNA transfection. Following this, the effectiveness of siIGFBP-rP1 transfection was measured by RT-qPCR and western blotting. IGFBP-rP1 expression exhibited a significant decrease in siIGFBP-rP1 duplex 1- and 2-transfected cells at the mRNA and protein levels $(\mathrm{P}<0.05$ vs. the blank control group; Fig. 1$)$. By contrast, there were no significant differences between the cells cultured in the blank control, transfection reagent and scramble control siRNA groups $(\mathrm{P}>0.05)$.

Moreover, the cell growth curve demonstrated that siIGFBP-rP1 duplex 1 and 2 significantly promoted RF/6A cell proliferation at 12, 24 and $48 \mathrm{~h}$ compared with the blank control group $(\mathrm{P}<0.01$; Fig. 2). No significant differences in cell viability were observed among the groups at 6 and $72 \mathrm{~h}$ $(\mathrm{P}>0.05)$. Furthermore, the siIGFBP-rP1 duplex 2 demonstrated a stronger pro-proliferative effect compared with the siIGFBP-rP1 duplex 1 at $24 \mathrm{~h}(\mathrm{P}<0.01)$. Since the siIGFBP-rP1 duplex 2 exhibited a higher inhibition efficiency and no cytotoxicity, it was selected for the following experiments.

IGFBP-rPl-silencing restores $R F / 6 A$ cell viability under hypoxia. As revealed in Fig. 3, the OD values of RF/6A cells detected by MTS colorimetric assay decreased significantly 

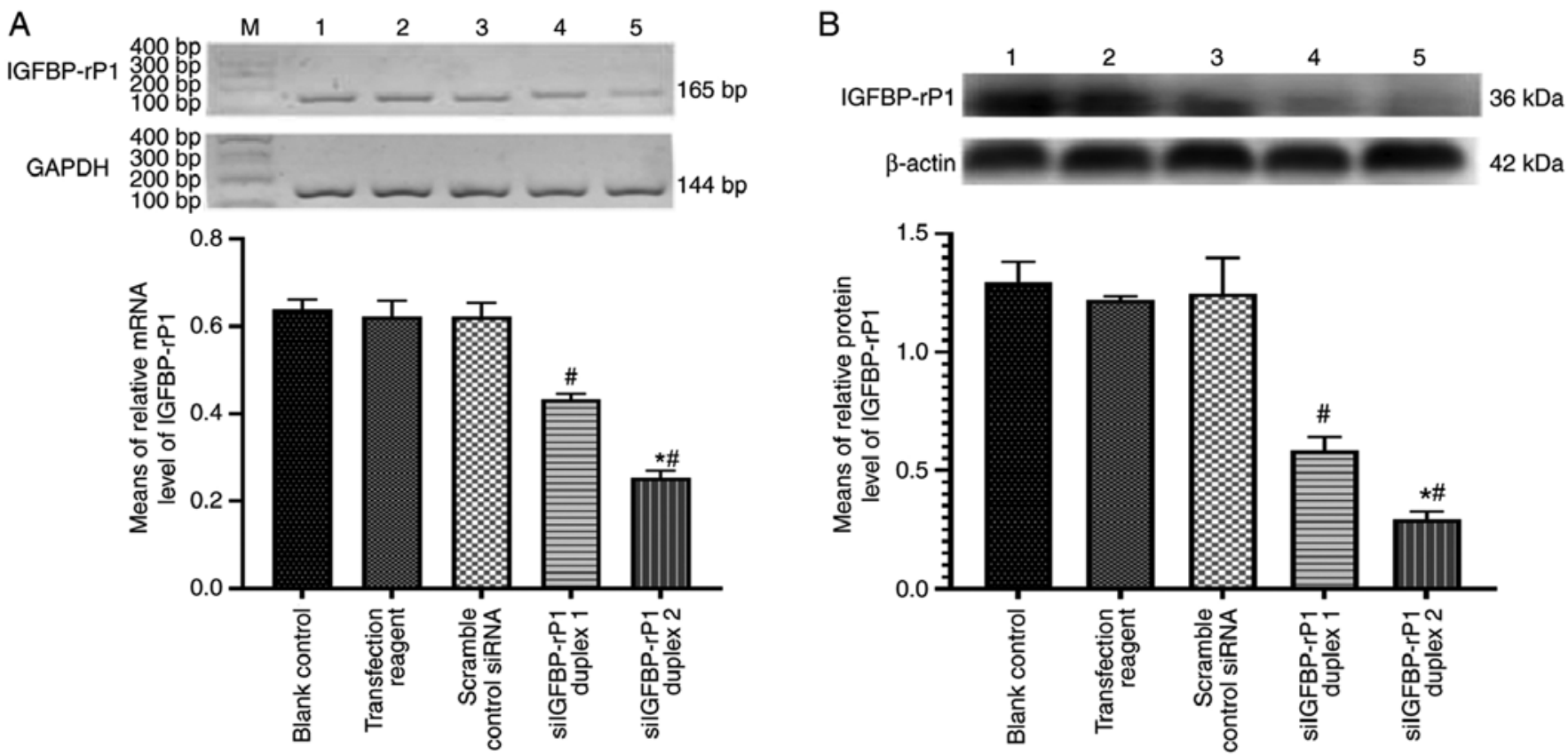

Figure 1. IGFBP-rP1-knockdown in RF/6A cells by siIGFBP-rP1. (A) Reverse transcription-quantitative PCR analysis of IGFBP-rP1 transcript expression in RF/6A cells. GAPDH served as an internal reference for control. Both siIGFBP-rP1 duplex 1 and 2 significantly inhibited the expression IGFBP-rP1 compared with controls $\left({ }^{\#} \mathrm{P}<0.05\right)$. Furthermore, the inhibitory effect of siIGFBP-rP1 duplex 2 was significantly increased compared with siIGFBP-rP1 duplex $1\left({ }^{*} \mathrm{P}<0.05\right)$. (B) IGFBP-rP1 expression was measured by western blotting and normalized to that of $\beta$-actin. The inhibitory effect of siIGFBP-rP1 on the IGFBP-rP1 protein expression was consistent with that of the RNA expression. The membranes were stripped off and probed for the proteins. Data are presented as the mean \pm standard deviation of three independent experiments with similar results and calculated as the integrated optical density of IGFBP-rP1 relative to the internal reference. ${ }^{\#} \mathrm{P}<0.01$ vs. the blank control group. ${ }^{*} \mathrm{P}<0.05$ vs. the siIGFBP-rP1 duplex 1 group. IGFBP-rP1, insulin-like growth factor binding protein-related protein 1; siIGFBP-rP1, IGFBP-rP1 specific siRNA. Lane M, marker; lane 1, blank control; lane 2, transfection reagent; lane 3, scrambled control siRNA; lane 4, siRNA duplex 1; lane 5, siRNA duplex 2.

following $12,24,48$ and $72 \mathrm{~h}$ of culturing in hypoxic environments, as compared with the control group, both at $200 \mu \mathrm{mol} / 1$ $\mathrm{CoCl}_{2}$ and at $1 \% \mathrm{O}_{2}$ compared with the controls $(\mathrm{P}<0.01)$. No significant difference was observed between the two hypoxic conditions $(\mathrm{P}>0.05)$. Following transfection with siIGFBP-rP1 for $24 \mathrm{~h}$, the OD values significantly increased following 12 , 24 and $48 \mathrm{~h}$ of culturing in normoxic conditions compared controls $(\mathrm{P}<0.01)$. Although the OD values of transfected cells cultured in hypoxic conditions for $12,24,48$ and $72 \mathrm{~h}$ were lower than those of transfected cells cultured in normoxic conditions, the values were still significantly higher compared with untransfected cells cultured in hypoxic conditions $(\mathrm{P}<0.01)$. No significant differences were observed among transfected cells cultured in hypoxic conditions and the control group at any time-point $(\mathrm{P}>0.05)$.

IGFBP-rP1-silencing stimulates hypoxia-induced migration and tube formation of RF/6A cells. In order to determine the effect of IGFBP-rP1-silencing on phenotype activation of $\mathrm{RF} / 6 \mathrm{~A}$ cells under $\mathrm{CoCl}_{2}$-induced hypoxic conditions, chemotactic motility and tube formation assays were performed on siIGFBP-rP1 transfected and untransfected cells under normal and hypoxic conditions. The scramble control siRNA-transfected cells were used as control cells.

The relative migration area of cells that had migrated from the edge of the wound and those that had migrated across the filter toward the lower surface due to hypoxia were $\sim 2.5 \mathrm{x}$ and $\sim 2 x$ that of the control, respectively (Fig. 4). siIGFBP-rP1 transfection significantly increased cell mobility compared with non-transfected cells, under both normoxic ( $\mathrm{P}<0.01$ vs. the hypoxia group) and hypoxic conditions $(\mathrm{P}<0.01 \mathrm{vs}$. the siIGFBP-rPI group).

As presented in Fig. 5, extensive and enclosed networks of capillary-like tubes were observed in the siIGFBP-rP1 and hypoxia + siIGFBP-rP1 groups, while incomplete and sparse tube networks formed by the untransfected cells under normal conditions. Tube formation, as determined by the total tube length, increased $~ 7$ - (the siIGFBP-rP1 group vs. the control group) or $\sim 5$-fold (the hypoxia + siIGFBP-rP1 group vs. the hypoxic group) following siIGFBP-rP1 transfection, as compared with non-transfection under normal or hypoxic conditions, respectively. Furthermore, tube length was significantly increased in the hypoxia group compared with the control group $(\mathrm{P}<0.01)$.

IGFBP-rPl-silencing enhances hypoxia-induced $R A F / M E K / E R K$ signaling pathway activation in $R F / 6 A$ cells. To understand the underlying mechanisms of restored cell viability, enhanced migration and tube formation by siIGFBP-rP1-transfected cells in hypoxic conditions, RF/6A cells cultured in normal conditions and $\mathrm{CoCl}_{2}$-induced hypoxic conditions with or without siIGFBP-rP1 transfection and exogenous human IGFBP-rP1 were detected to determine the changes of key molecules in the RAF/MEK/ERK signaling pathway using western blotting. As revealed in Fig. 6, under hypoxic conditions, the expression of B-RAF, p-MEK and p-ERK were significantly increased compared with that under normal conditions 


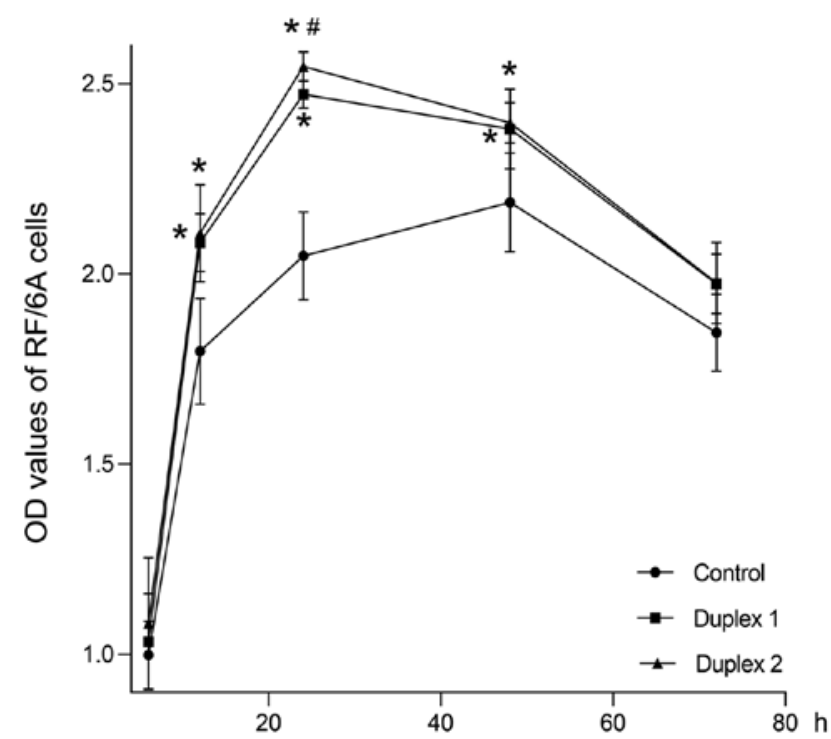

Figure 2. Cell growth curves of siIGFBP-rP1-transfected cells and untransfected cells cultured in normoxic conditions for $6,12,24,48$ and $72 \mathrm{~h}$. The OD values of transfected cells at 12,24 and $48 \mathrm{~h}$ were significantly higher compared with untransfected cells $\left({ }^{*} \mathrm{P}<0.01\right)$. Furthermore, the OD value of siIGFBP-rP1 duplex 2-transfected cells was significantly higher compared with siIGFBP-rP1 duplex 1-transfected cells at $24 \mathrm{~h}\left({ }^{\#} \mathrm{P}<0.01\right)$. No significant differences were observed among the groups at 6 and $72 \mathrm{~h}$. OD values are presented as the mean \pm standard deviation of 4 wells/group and experiments were performed in triplicate. IGFBP-rP1, insulin-like growth factor binding protein-related protein 1; siIGFBP-rP1, IGFBP-rP1 specific siRNA; OD, optical density.

$(\mathrm{P}<0.05)$. In addition, following IGFBP-rP1-silencing, the phosphorylation level of the RAF/MEK/ERK signaling pathway was significantly increased, both under normal (the siIGFBP-rP1 group vs. the control group, $\mathrm{P}<0.05$ ) and hypoxic conditions (the hypoxia + siIGFBP-rP1 group vs. the hypoxia group, $\mathrm{P}<0.05)$. Furthermore, with the addition of exogenous human IGFBP-rP1, the upregulation of B-RAF, p-MEK and p-ERK induced by siIGFBP-rP1 transfection significantly decreased $(\mathrm{P}<0.01)$. No significant differences in the expression of MEK and ERK were observed between the six groups (data not shown).

IGFBP-rPl-silencing upregulates the hypoxia-induced $V E G F$ expression in RF/6A cells. Since VEGF expression may be involved in the process of choroidal angiogenesis mediated by IGFBP-rP1 (12), western blotting was performed to detect the distinct protein expression of VEGF under different intervention conditions. As presented in Fig. 6, the expression of VEGF increased $\sim 4$ - or $\sim 7$ fold in the hypoxia group and siIGFBP-rP1 group, respectively, compared with control. When the transfected cells were cultured in hypoxic conditions, the expression of VEGF significantly increased ( $\sim$-fold), compared with control. Additionally, the upregulation of VEGF in siIGFBP-rP1-transfected cells under hypoxic conditions was markedly increased compared with transfected cells under normal conditions $(\mathrm{P}<0.01$; data not shown). Similar to the RAF/MEK/ERK pathway, exogenous human IGFBP-rP1 significantly downregulated the expression of VEGF in siIGFBP-rP1-transfected cells, under both normoxic and hypoxic conditions $(\mathrm{P}<0.01)$.

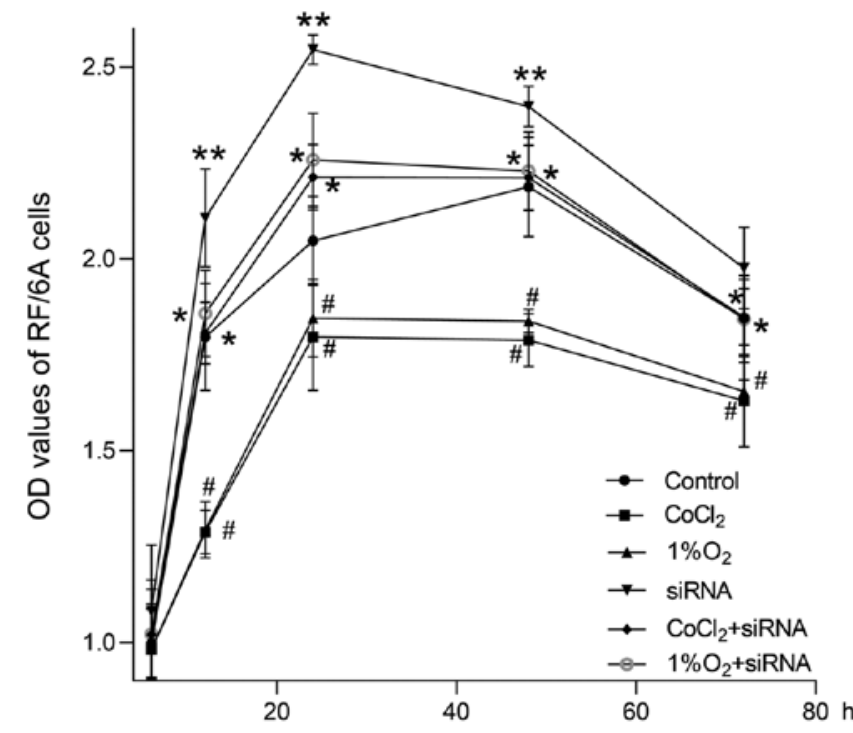

Figure 3. Cell growth curves of siIGFBP-rP1-transfected or untransfected cells cultured under normoxic or hypoxic conditions for $6,12,24,48$ and $72 \mathrm{~h}$, as detected by MTS colorimetric assays. The OD values of hypoxic groups $\left(\mathrm{CoCl}_{2}\right.$ and $\left.1 \% \mathrm{O}_{2}\right)$ decreased significantly at $12,24,48$ and $72 \mathrm{~h}$ compared with the control group $\left({ }^{\#} \mathrm{P}<0.01\right)$. There was no significant difference between the hypoxic groups $(\mathrm{P}>0.05)$. The OD value of the siRNA group were significantly increased at 12,24 and $48 \mathrm{~h}$ compared with controls $\left({ }^{* *} \mathrm{P}<0.01\right)$. Furthermore, the OD values of the transfected cells cultured in hypoxic conditions $\left(\mathrm{CoCl}_{2}+\right.$ siRNA group and $1 \% \mathrm{O}_{2}+$ siRNA group) for $12,24,48$ and $72 \mathrm{~h}$ were significantly lower compared with the siRNA group; additionally, the values were significantly higher compared with the hypoxic groups $\left({ }^{*} \mathrm{P}<0.01\right)$. No significant differences were identified between the $\mathrm{CoCl}_{2}+$ siRNA, $1 \% \mathrm{O}_{2}+$ siRNA and control groups $(\mathrm{P}>0.05)$. OD values are presented as the mean \pm standard deviation of 4 wells/group and experiments were performed in triplicate. IGFBP-rP1, insulin-like growth factor binding protein-related protein 1; siIGFBP-rP1, IGFBP-rP1 specific siRNA; $\mathrm{CoCl}_{2}$, cobalt chloride; $\mathrm{OD}$, optical density.

\section{Discussion}

The number of patients with AMD, a common age-associated eye disease, is increasing worldwide due to exponential population ageing. The projected number of individuals with AMD for 2020 is 196 million, with an expected increase to 288 million in 2040 (21,22). Since 2010, AMD has become the 3rd most common cause of blindness and the 4th leading cause of visual impairment worldwide (23). IGFs, the family of important proteins that regulate various cellular processes, including proliferation, differentiation, apoptosis and neovascularization, may be involved in molecular mechanisms that contribute to the pathogenesis of AMD, involving oxidative stress, mitochondrial dysfunction and impaired resistance to molecular stressors in the choriocapillaris (24-30). The members of the IGF family, including IGFBP-2, IGFBP-6 and IGFBP-rP1, were demonstrated to be increased in patients with exudative AMD (31). However, further research reported that IGFBP-rP1 was decreased in patients with neovascular AMD (14). This difference in IGFBP-rP1 expression highlighted the possibility of IGFBP-rP1 being an endogenous factor regulating AMD progression.

The IGFBP-rP1 gene is located on chromosome $4 \mathrm{q}$ and encodes a 256 -amino acid protein $(10,11)$. IGFBP-rP1 is distinct from other IGFBPs, as it can highly bind to insulin yet lowly to IGFs and IGFBP-rP1 has been demonstrated to 
A
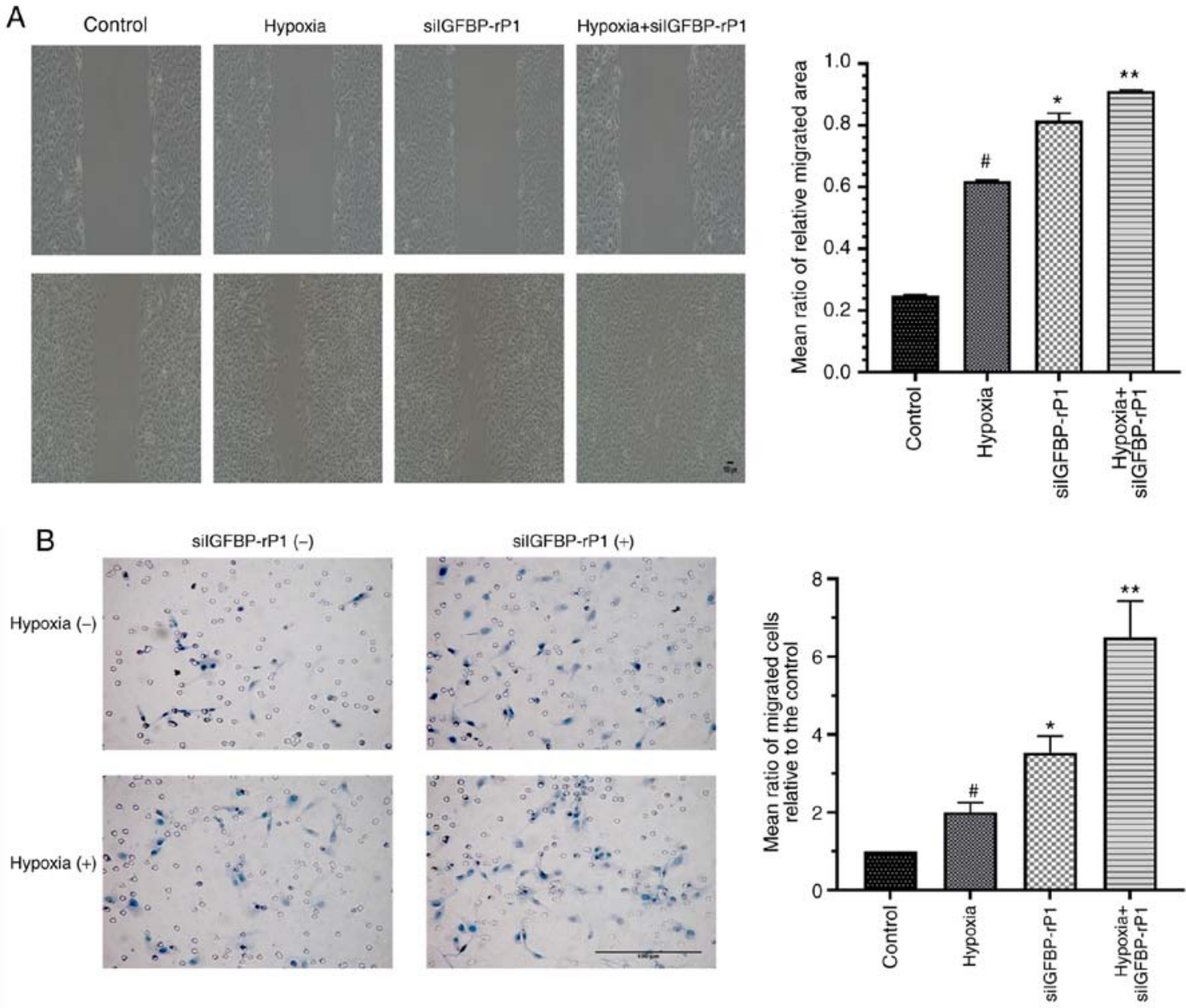

Figure 4. Cell motility of siIGFBP-rP1-transfected or untransfected cells cultured under normoxic or hypoxic conditions for $24 \mathrm{~h}$ is detected by wound and Transwell assays. (A) Representative images showing that RF/6A cells migrated across the wound boundary to the blank area (light microscopy; magnification, $\mathrm{x} 400$ ) and (B) passed across the filter toward the lower surface (light microscopy; magnification, x200). Hypoxia significantly promoted cell mobility compared with the controls $\left({ }^{*} \mathrm{P}<0.01\right)$. siIGFBP-rP1 transfection (siIGFBP-rP1 group) further enhanced cell migration, as compared with untransfected cells cultured in hypoxic conditions (hypoxia group; ${ }^{*} \mathrm{P}<0.01$ ). The transfected cells cultured in hypoxic conditions (hypoxia + siRNA group) exhibited a significantly increased migration ability compared with the transfected cells cultured in normoxic conditions (siIGFBP-rP1 group; $\left.{ }^{* *} \mathrm{P}<0.01\right)$. Values are presented as the mean \pm standard deviation of 4 samples/group and experiments were performed in triplicate and are quantified as the ratio relative to the control group. IGFBP-rP1, insulin-like growth factor binding protein-related protein 1; siIGFBP-rP1, IGFBP-rP1 specific siRNA.
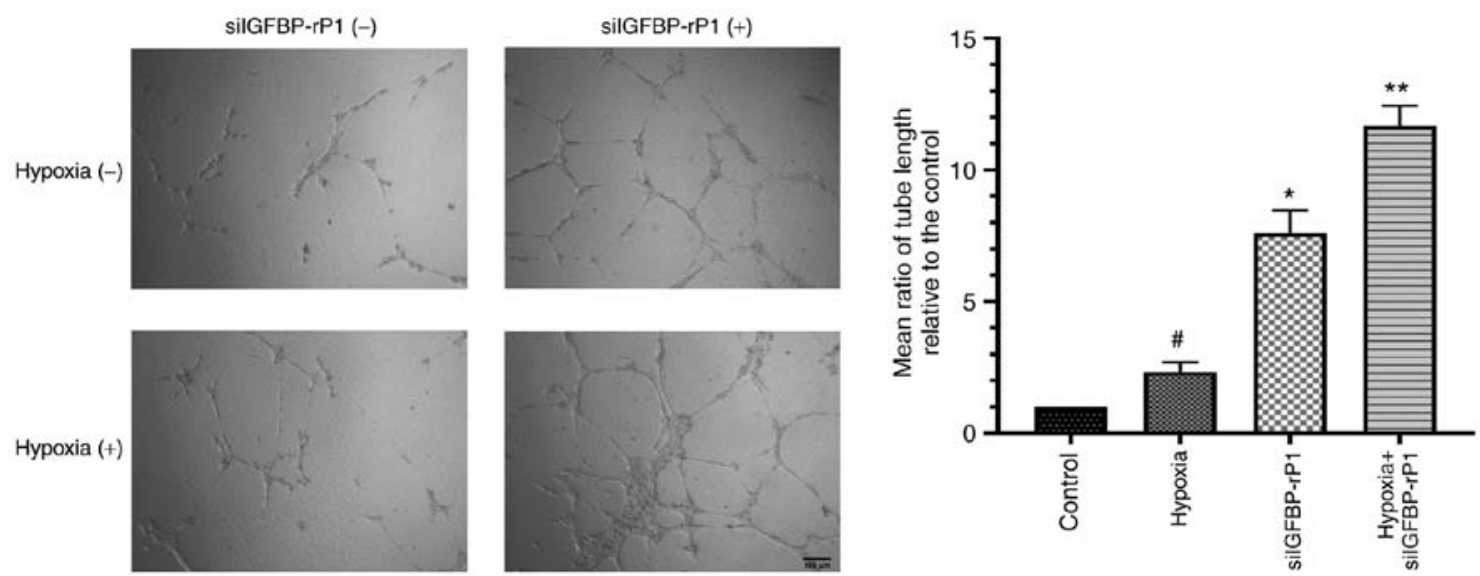

Figure 5. IGFBP-rP1-silencing stimulates hypoxia-induced tube formation of RF/6A cells. Representative images (inverted phase contrast microscopy; magnification, $\mathrm{x} 50$ ) demonstrating that $\mathrm{RF} / 6 \mathrm{~A}$ cells formed capillary-like tube structures within the Matrigel layer in different mediums. $\mathrm{RF} / 6 \mathrm{~A}$ cells in hypoxic conditions or siIGFBP-rP1-transfected cells significantly formed completely enclosed capillary-like tubes compared with the controls $\left({ }^{*} \mathrm{P}<0.01\right.$ the hypoxia group vs. the control group; ${ }^{\mathrm{P}}<0.01$ the siIGFBP-rP1 group vs. the control group). Moreover, siIGFBP-rP1 transfection further promoted tube formation in RF/6A cells in the hypoxia + siIGFBP-rP1 group compared with the siIGFBP-rP1 group $(* * \mathrm{P}<0.01)$. The values are presented as the mean \pm standard deviation of 4 samples/group and experiments were performed in triplicate and are quantified as the ratio relative to the control group. IGFBP-rP1, insulin-like growth factor binding protein-related protein 1; siIGFBP-rP1, IGFBP-rP1 specific small interfering RNA. 

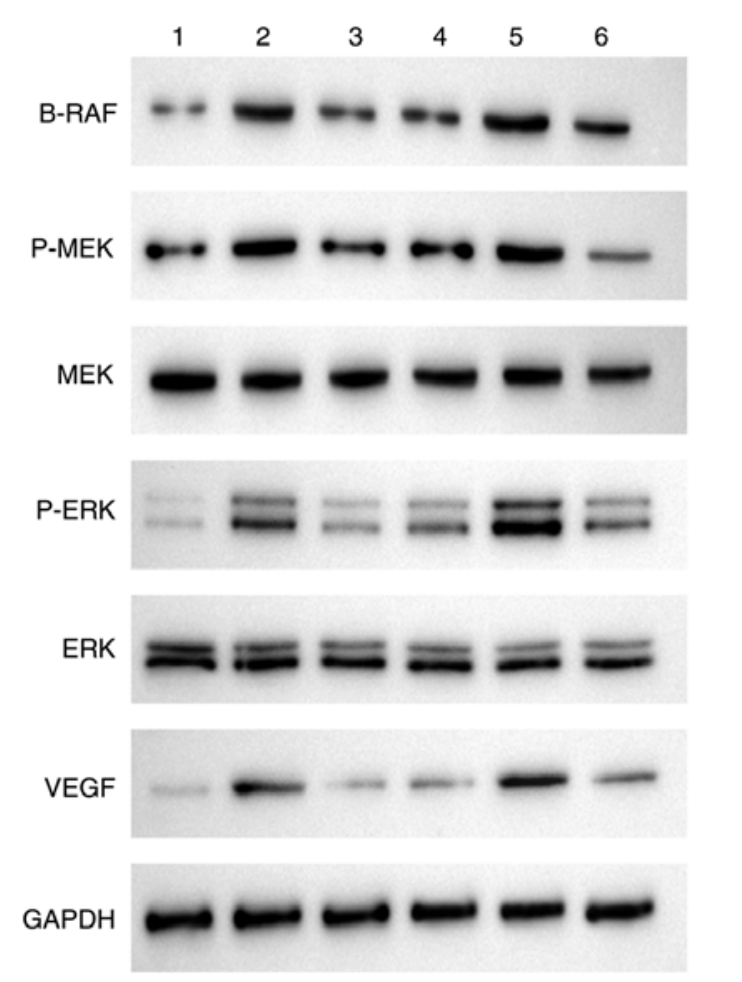
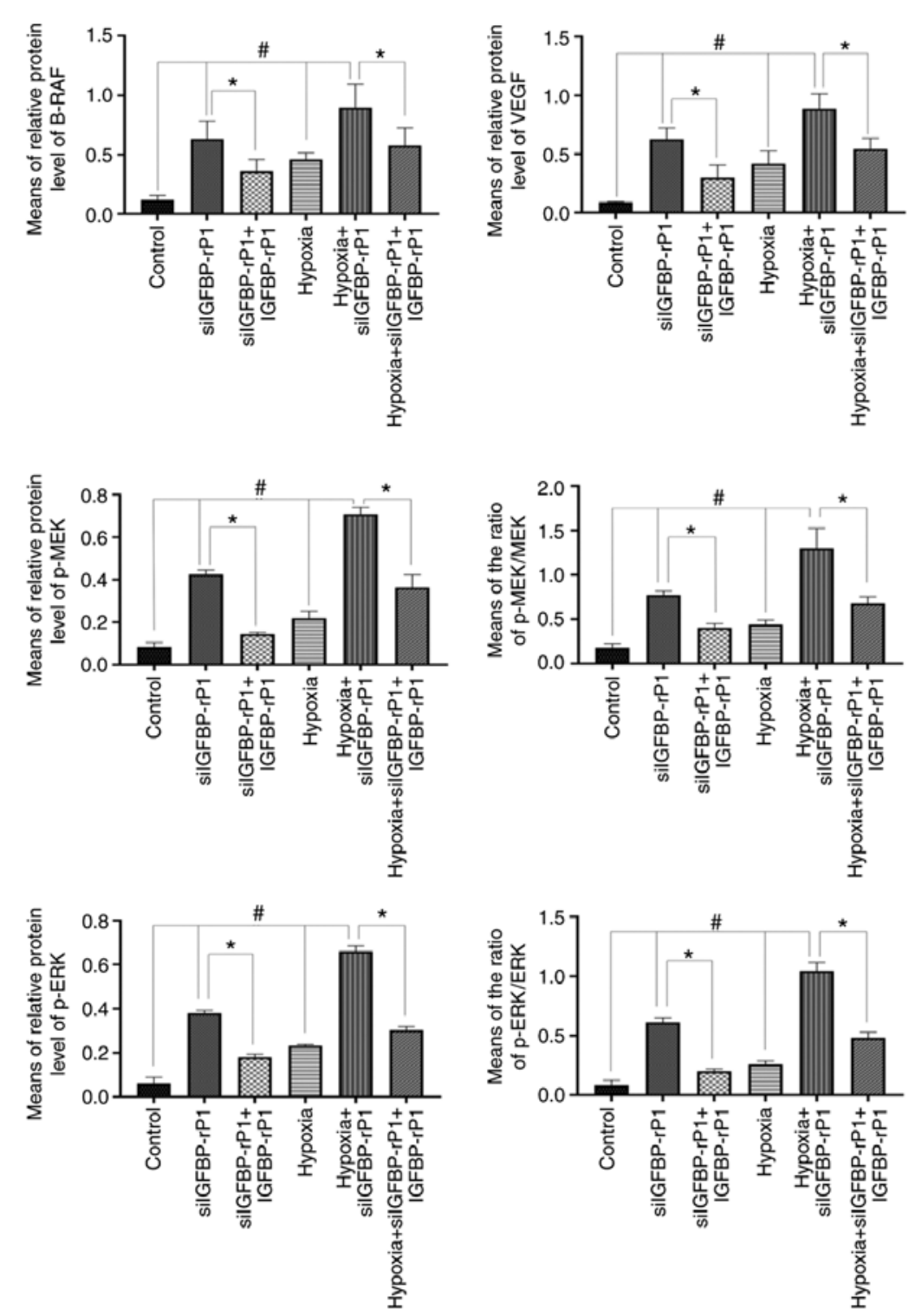

Figure 6. IGFBP-rP1-silencing upregulates the hypoxia-induced RAF/MEK/ERK signaling pathway activation and VEGF expression. Representative images and quantified data demonstrated that hypoxic stress upregulated B-RAF, p-MEK, $\mathrm{p}$-ERK and VEGF expression in RF/6A cells compared with controls ( ${ }^{\#} \mathrm{P}<0.05$ ). siIGFBP-rP1 transfection significantly promoted hypoxia-induced B-RAF, p-MEK, p-ERK and VEGF expression in RF/6A compared with the hypoxia group $\left({ }^{\prime} \mathrm{P}<0.05\right)$. IGFBP-rP1 restoration significantly downregulated the expression of B-RAF, p-MEK, p-ERK and VEGF in siIGFBP-rP1-transfected cells, under both normoxic and hypoxic conditions, compared with the siIGFBP-rP1 and hypoxia + siIGFBP-rP1 groups, respectively $(" \mathrm{P}<0.01)$. The membranes were stripped off and probed for the proteins. Values are presented as the mean $\pm \mathrm{SD}$ of 3 independent experiments with similar results and are presented as the integrated optical density of studied proteins relative to GAPDH. IGFBP-rP1, insulin-like growth factor binding protein-related protein 1; siIGFBP-rP1, IGFBP-rP1 specific siRNA. Lane 1, control; lane 2, siIGFBP-rP1; lane 3, siIGFBP-rP1 + IGFBP-rP1; lane 4, hypoxia; lane 5, hypoxia + siIGFBP-rP1; lane 6, hypoxia + s iIGFBP-rP1 + IGFBP-rP1.

have various functions in different cellular contexts $(10,11)$. IGFBP-rP1 was described to have both tumor suppressing and enhancing properties in regard to cell proliferation (32). Additionally, IGFBP-rP1 was associated with the senescence and apoptosis of different cell lines, including human breast cancer cell lines and prostate cancer cell lines $(33,34)$. Previous studies revealed a stimulatory effect of IGFBP-rP1 in the adhesion, migration and proliferation of acute myeloid leukemia $(35,36)$. Accumulating evidence has indicated that IGFBP-rP1 downregulation may participate in tumorigenesis, acting as a cancer suppressive factor in various types of cancer, including breast, colorectal, prostate and hepatocellular cancer (37-40). Our previous study revealed that IGFBP-rP1 inhibited the stimulatory effect of VEGF on retinal angiogenesis in vitro (12). It was also revealed that IGFBP-rP1 inhibited ocular neovascularization by downregulating VEGF expression in a mouse model of $\mathrm{O}_{2}$-induced retinopathy (13). Furthermore, IGFBP-rP1 was confirmed to be downregulated in the aqueous humor of patients with wet AMD; however, the downregulation of IGFBP-rP1 in the pathogenesis of wet AMD remains unknown (14).

In order to examine the effects of IGFBP-rP1 on the biological behavior of choroidal endothelial cells under a pathological state, gene silencing was performed to interfere with the expression of IGFBP-rP1 in choroidal endothelial cells and hypoxic conditions were used to mimic the internal 
environment in patients with AMD. RF/6A cells, a rhesus choroid endothelial cell line widely used in research to simulate ophthalmic micro-endothelial cells and explore the influences of external factors and corresponding mechanisms $(15-17,41,42)$ were used to observe the influence of IGFBP-rP1-silencing and hypoxia on CNV formation in vitro. RNA interference, which allows for the silencing of mammalian genes with great specificity and potency, has been extensively used in several fields to investigate gene functions and design novel therapeutic methods (43-48). Using this technique, IGFBP-rP1-silencing was successfully accomplished in RF/6A cells. Cell growth curves confirmed that siIGFBP-rP1 duplex 1 and 2 both significantly promoted $\mathrm{RF} / 6 \mathrm{~A}$ cell proliferation at 12, 24 and $48 \mathrm{~h}$, and silGFBP-rP1 duplex 2 demonstrated a more significant effect compared with duplex 1 at 24 h. Furthermore, no significant differences were observed between the transfected cells and untransfected cells at 6 and $72 \mathrm{~h}$. These results suggested that there was no significant impairment in cell viability following the silencing of IGFBP-rP1 expression at 6-72 $\mathrm{h}$.

Hypoxia is considered to serve an important role in $\mathrm{CNV}$ formation, a critical characteristic of wet AMD and the main cause of visual impairment in patients with subsequent bleeding or fibrosis (6-8,49-51). $\mathrm{CoCl}_{2}$-induced chemical hypoxia, a reliable method of mimicking hypoxia (52-55), was used to imitate the internal environment during choroidal angiogenesis. Since $\mathrm{CoCl}_{2}$ can unexpectedly and markedly decrease pyruvate dehydrogenase phosphorylation and lead to an enhanced glycolytic poise in mammalian cells (56), the different effects between $\mathrm{CoCl}_{2}$ mimetic and $1 \% \mathrm{O}_{2}$-induced hypoxia on cell proliferation were compared. Both hypoxic conditions significantly decreased cell proliferation and IGFBP-rP1-silencing restored cell viability in these hypoxic conditions. The difference on cell proliferation was not obvious between these two types of hypoxic environment under the current experimental conditions, thus the present study continued to use $\mathrm{CoCl}_{2}$ mimetic hypoxia in subsequent experiments. The results demonstrated that hypoxic conditions significantly enhanced migration and capillary-like tube formation in RF/6A cells. These results indicated that abnormal environments, including hypoxia, serve an important role in the development of CNV formation, which was consistent with previous studies $(54,55,57)$.

The present study further explored the role of IGFBP-rP1-silencing in the angiogenic potential of RF/6A cells under hypoxic conditions. The results demonstrated that the transfected cells under hypoxia were significantly activated to migrate from the edge of the wound, pass across the filter toward the lower surface and form extensive and enclosed networks of capillary-like tubes compared with controls. The migrated area and number of silGFBP-rP1 transfected cells in hypoxic conditions, as well as total tube length, were significantly higher compared with siIGFBP-rP1 transfected cells in normal conditions. These results indicated that the downregulation of IGFBP-rP1 significantly promoted vascular branching and sprouting under hypoxia, which implied that IGFBP-rP1 may act as an anti-angiogenic regulator of choroidal angiogenesis. During the process of AMD-related choroidal vascular homeostasis deterioration and neovascularization, the downregulation of anti-angiogenic factors has been demonstrated to be a common pathological manifestation (58-61).
This may explain why the concentration of IGFBP-rP1 in the aqueous humor of patients with wet AMD was significantly lower compared with controls (14). Along with excessively synthesized and released VEGF in the hypoxic eyes of these patients $(9,62)$, the balance was further disrupted by the downregulation of IGFBP-rP1, which may significantly accelerate the occurrence and development of CNV.

The RAF/MEK/ERK signaling pathway serves a critical role in regulating cell division, proliferation, senescence and apoptosis during physiological and pathological processes, such as adipocyte physiology, insulin signaling, oxidative stress and cancer progression (63-66). Excessive activation of the key molecules of this signaling pathway in the majority of types of cancer results in an unbalanced cell proliferation and apoptosis inhibition or escapement $(67,68)$. Additionally, it has been confirmed that the activation of the RAF/MEK/ERK signaling pathway modulated the role of VEGF in tumor pathogenesis and metastasis (69-72). The present study demonstrated that the RAF/MEK/ERK signaling pathway was significantly activated when choroidal endothelial cells cultured under hypoxic conditions were transfected with siIGFBP-rP1, while exogenous IGFBP-rP1 downregulated the activation level of this pathway. IGFBP-rP1 may promote the pro-angiogenic effect of VEGF, particularly in pathological conditions, including hypoxia, which was reported by the present results. Furthermore, the results of the present study revealed that the hypoxia-induced VEGF expression was significantly upregulated in RF/6A cells by blocking IGFBP-rP1 expression. The regulation of VEGF expression demonstrated the same trend as the activation of the RAF/MEK/ERK signaling pathway. Additionally, previous studies have indicated that the RAF/MEK/ERK signaling pathway regulated VEGF expression in diabetic animals $(73,74)$ and hypoxic conditions $(75,76)$. These results suggested that IGFBP-rP1 may regulate VEGF expression in choroidal endothelial cells through the RAF/MEK/ERK signaling pathway under hypoxia. In combination, the inhibition of IGFBP-rP1 further activated the RAF/MEK/ERK signaling pathway and upregulated VEGF expression, which may concurrently participate in choroidal endothelial cell phenotype activation, CNV formation and AMD progression under hypoxia. Since patients with partial wet AMD have a poor or no response to anti-VEGF treatment, novel drugs that can resolve this problem are urgently required. IGFBP-rP1 may become a therapeutic target in choroidal angiogenesis due to its potential inhibition of ophthalmic neovascularization.

The present study had limitations. Although there was no significant difference in cell viability between $\mathrm{CoCl}_{2}$ mimetic and $1 \% \mathrm{O}_{2}$-induced hypoxia, certain effects induced by $\mathrm{CoCl}_{2}$ may differ from those of actual hypoxia. Therefore, the role of IGFBP-rP1 in RF/6A cells under physical hypoxia requires further investigation. Furthermore, despite the extensive application of RF/6A cells as the closest choroidal endothelial cell line to human species in studies on choroidal angiogenesis in vitro, the signaling circuitry has been altered in this immortalized cell line. Therefore, the exact effect of IGFBP-rP1 on choroidal angiogenesis and the RAF/MEK/ERK signaling pathway needs to be further explored in human choroidal endothelial cells and in an in vivo model.

In conclusion, the present study revealed that IGFBP-rP1-silencing promoted cell proliferation and stimulated 
hypoxia-induced migration and tube formation of RF/6A cells . Additionally, the results confirmed that IGFBP-rP1-silencing effectively promoted hypoxia-induced angiogenic potential of choroidal endothelial cells by upregulating VEGF expression, probably by activating the RAF/MEK/ERK signaling pathway. Further research should be conducted to determine whether IGFBP-rP1 acts as an angiogenesis inhibitor in vivo and its effect on other ocular tissues; the real-world application of IGFBP-rP1 or an associated drug in clinical practice requires further research in future studies.

\section{Acknowledgements}

Not applicable.

\section{Funding}

The present study was supported by grants from the National Nature Science Foundation for Young Scholars of China (grant no. 81200701), the National Key R\&D Program of China (grant nos. 2016YFC0904800 and 2019YFC0840607), the National Science and Technology Major Project of China (grant no. 2017ZX09304010) and the Bethune-Lumitin Research Funding for Young or Middle-aged Ophthalmologists (grant no. BJ-LM2019001J).

\section{Availability of data and materials}

The datasets used and/or analyzed during the current study are available from the corresponding author on reasonable request.

\section{Authors' contributions}

SZ and HW conducted the siRNA assays, the restoration assays, data acquisition and were major contributors in drafting the original manuscript. MM and ZZha performed the cell viability assays, cell motility assays, tube formation assays, created graphs and were major contributors in drafting the original manuscript. ZZhe and HW performed the signaling pathway assays, analysis and interpretation of data and made major contributions in editing the original manuscript. XX and TS made substantial contributions to conception and design, and made critical revising of the original manuscript. All authors read and approved the final manuscript.

\section{Ethics approval and consent to participate}

Not applicable.

\section{Patient consent for publication}

Not applicable.

\section{Competing interests}

The authors declare that they have no competing interests.

\section{References}

1. Yancopoulos GD, Davis S, Gale NW, Rudge JS, Wiegand SJ and Holash J: Vascular-specific growth factors and blood vessel formation. Nature 407: 242-248, 2000.
2. Daien V, Eldem BM, Talks JS, Korobelnik JF, Mitchell P, Finger RP, Sakamoto T, Wong TY, Evuarherhe O, Carter G and Carrasco J: Real-world data in retinal diseases treated with anti-vascular endothelial growth factor (anti-VEGF) therapy-a systematic approach to identify and characterize data sources. BMC Ophthalmol 19: 206, 2019.

3. Campbell M and Doyle SL: Current perspectives on established and novel therapies for pathological neovascularization in retinal disease. Biochem Pharmacol 164: 321-325, 2019.

4. Campochiaro PA: Molecular pathogenesis of retinal and choroidal vascular diseases. Prog Retin Eye Res 49: 67-81, 2015.

5. Wang H, Chai Z, Hu D, Ji Q, Xin J, Zhang C and Zhong J: A global analysis of $\mathrm{CNVs}$ in diverse yak populations using whole-genome resequencing. BMC Genomics 20: 61, 2019.

6. Park SM, Lee K, Huh M, Eom S, Park B, Kim KH, Park DH, Kim DS and Kim HK: Development of an in vitro 3D choroidal neovascularization model using chemically induced hypoxia through an ultra-thin, free-standing nanofiber membrane. Mater Sci Eng C Mater Biol Appl 104: 109964, 2019.

7. Alivand MR, Sabouni F and Soheili ZS: Probable chemical hypoxia effects on progress of CNV through induction of promoter $\mathrm{CpG}$ demethylation and overexpression of IL17RC in human RPE cells. Curr Eye Res 41: 1245-1254, 2016.

8. Andre H, Tunik S, Aronsson M and Kvanta A: Hypoxia-inducible factor- $1 \alpha$ is associated with sprouting angiogenesis in the murine laser-induced choroidal neovascularization model. Invest Ophthalmol Vis Sci 56: 6591-6604, 2015.

9. Penn JS, Madan A, Caldwell RB, Bartoli M, Caldwell RW and Hartnett ME: Vascular endothelial growth factor in eye disease. Prog Retin Eye Res 27: 331-371, 2008.

10. Hwa V, Oh Y and Rosenfeld RG: The insulin-like growth factor-binding protein (IGFBP) superfamily. Endocr Rev 20: 761-787, 1999.

11. Forbes BE, McCarthy P and Norton RS: Insulin-like growth factor binding proteins: A structural perspective. Front Endocrinol (Lausanne) 3: 38, 2012.

12. Sun T, Cao H, Xu L, Zhu B, Gu Q and Xu X: Insulin-like growth factor binding protein-related protein 1 mediates VEGF-induced proliferation, migration and tube formation of retinal endothelial cells. Curr Eye Res 36: 341-349, 2011.

13. Zhang P, Wang H, Cao H, Xu X and Sun T: Insulin-like growth factor binding protein-related protein 1 inhibit retinal neovascularization in the mouse model of oxygen-induced retinopathy. J Ocul Pharmacol Ther 33: 459-465, 2017.

14. Sung HJ, Han JI, Lee JW, Uhm KB and Heo K: TCCR/WSX-1 is a novel angiogenic factor in age-related macular degeneration. Mol Vis 18: 234-240, 2012.

15. Zhu M, Liu X, Wang S, Miao J, Wu L, Yang X, Wang Y, Kang L, Li W, Cui C, et al: PKR promotes choroidal neovascularization via upregulating the PI3K/Akt signaling pathway in VEGF expression. Mol Vis 22: 1361-1374, 2016.

16. Feng Y, Wang J, Yuan Y, Zhang X, Shen M and Yuan F: miR-539-5p inhibits experimental choroidal neovascularization by targeting CXCR7. Faseb J 32: 1626-1639, 2018.

17. Chan C, Hsiao C, Li H, Fang J, Chang D and Hung C: The inhibitory effects of gold nanoparticles on VEGF-A-induced cell migration in choroid-retina endothelial cells. Int J Mol Sci 21: 109,2019

18. Liu Z, Liu H, Fang W, Yang Y, Wang H and Peng J: Insulin-like growth factor binding protein 7 modulates estrogen-induced trophoblast proliferation and invasion in HTR-8 and JEG-3 cells. Cell Biochem Biophys 63: 73-84, 2012.

19. Tamura K, Yoshie M, Hashimoto K and Tachikawa E: Inhibitory effect of insulin-like growth factor-binding protein-7 (IGFBP7) on in vitro angiogenesis of vascular endothelial cells in the rat corpus luteum. J Reprod Dev 60: 447-453, 2014.

20. Verhagen HJMP, van Gils N, Martiañez T, van Rhenen A, Rutten A, Denkers F, de Leeuw DC, Smit MA, Tsui M, de Vos Klootwijk LLE, et al: IGFBP7 induces differentiation and loss of survival of human acute myeloid leukemia stem cells without affecting normal hematopoiesis. Cell Rep 25: 3021-3035, 2018.

21. Rozing MP, Durhuus JA, Krogh NM, Subhi Y, Kirkwood TB, Westendorp RG and Sørensen TL: Age-related macular degeneration: A two-level model hypothesis. Prog Retin Eye Res 100825: 2019. 
22. Wong WL, Su X, Li X, Cheung CM, Klein R, Cheng CY and Wong TY: Global prevalence of age-related macular degeneration and disease burden projection for 2020 and 2040: A systematic review and meta-analysis. Lancet Glob Health 2: e106-e116, 2014.

23. Pascolini D and Mariotti SP: Global estimates of visual impairment: 2010. Br J Ophthalmol 96: 614-618, 2012.

24. Lipecz A, Miller L, Kovacs I, Czako C, Csipo T, Baffi J, Csiszar A, Tarantini S, Ungvari Z, Yabluchanskiy A and Conley S: Microvascular contributions to age-related macular degeneration (AMD): From mechanisms of choriocapillaris aging to novel interventions. Geroscience 41: 813-845, 2019.

25. Lambert NG, ElShelmani H, Singh MK, Mansergh FC, Wride MA, Padilla M, Keegan D, Hogg RE and Ambati BK Risk factors and biomarkers of age-related macular degeneration. Prog Retin Eye Res 54: 64-102, 2016.

26. Pan $\mathrm{H}$ and Finkel T: Key proteins and pathways that regulate lifespan. J Biol Chem 292: 6452-6460, 2017.

27. Jesko H, Stepien A, Lukiw WJ and Strosznajder RP: The cross-talk between sphingolipids and insulin-like growth factor signaling: Significance for aging and neurodegeneration. Mol Neurobiol 56: 3501-3521, 2019.

28. Haywood NJ, Slater TA, Matthews CJ and Wheatcroft SB: The insulin like growth factor and binding protein family: Novel therapeutic targets in obesity \& diabetes. Mol Metab 19: 86-96, 2019.

29. Slater T, Haywood NJ, Mathews C, Cheema $H$ and Wheatcroft SB: Insulin-like growth factor binding proteins and angiogenesis: From cancer to cardiovascular disease. Cytokine Growth Factor Rev 46: 28-35, 2019.

30. Bach LA: Endothelial cells and the IGF system. J Mol Endocrinol 54: R1-R13, 2015.

31. Cha DM, Woo SJ, Kim HJ, Lee C and Park KH: Comparative analysis of aqueous humor cytokine levels between patients with exudative age-related macular degeneration and normal controls. Invest Ophthalmol Vis Sci 54: 7038-7044, 2013.

32. Zhu S, Xu F, Zhang J, Ruan W and Lai M: Insulin-like growth factor binding protein-related protein 1 and cancer. Clin Chim Acta 431: 23-32, 2014

33. Wilson HM, Birnbaum RS, Poot M, Quinn LS and Swisshelm K Insulin-like growth factor binding protein-related protein 1 inhibits proliferation of MCF-7 breast cancer cells via a senescence-like mechanism. Cell Growth Differ 13: 205-213, 2002.

34. Mutaguchi K, Yasumoto H, Mita K, Matsubara A, Shiina H, Igawa M, Dahiya R and Usui T: Restoration of insulin-like growth factor binding protein-related protein 1 has a tumor-suppressive activity through induction of apoptosis in human prostate cancer. Cancer Res 63: 7717-7723, 2003.

35. Hu S, Chen R, Man X, Feng X, Cen J, Gu W, He H, Li J, Chai Y and Chen Z: Function and expression of insulin-like growth factor-binding protein 7 (IGFBP7) gene in childhood acute myeloid leukemia. Pediatr Hematol Oncol 28: 279-287, 2011.

36. Laranjeira AB, de Vasconcellos JF, Sodek L, Spago MC, Fornazim MC, Tone LG, Brandalise SR, Nowill AE and Yunes JA: IGFBP7 participates in the reciprocal interaction between acute lymphoblastic leukemia and BM stromal cells and in leukemia resistance to asparaginase. Leukemia 26: 1001-1011, 2012.

37. Burger AM, Leyland-Jones B, Banerjee K, Spyropoulos DD and Seth AK: Essential roles of IGFBP-3 and IGFBP-rP1 in breast cancer. Eur J Cancer 41: 1515-1527, 2005.

38. Zhu S, Zhang J, Xu F, Xu E, Ruan W, Ma Y, Huang Q and Lai M: IGFBP-rP1 suppresses epithelial-mesenchymal transition and metastasis in colorectal cancer. Cell Death Dis 6: e1695, 2015.

39. Seki M, Teishima J, Mochizuki H, Mutaguchi K, Yasumoto $H$ Oka K, Nagamatsu H, Shoji K and Matsubara A: Restoration of IGFBP-rP1 increases radiosensitivity and chemosensitivity in hormone-refractory human prostate cancer. Hiroshima J Med Sci 62: 13-19, 2013.

40. Akiel M, Guo C, Li X, Rajasekaran D, Mendoza RG, Robertson CL, Jariwala N, Yuan F, Subler MA, Windle J, et al: IGFBP7 deletion promotes hepatocellular carcinoma. Cancer Res 77: 4014-4025, 2017.

41. Jiang H, Wu M, Liu Y, Song L, Li S, Wang X, Zhang YF, Fang J and $\mathrm{Wu} \mathrm{S}$ : Serine racemase deficiency attenuates choroidal neovascularization and reduces nitric oxide and VEGF levels by retinal pigment epithelial cells. J Neurochem 143: 375-388, 2017.
42. Chen S, Zhou Y, Zhou L, Guan Y, Zhang Y and Han X: Anti-neovascularization effects of DMBT in age-related macular degeneration by inhibition of VEGF secretion through ROS-dependent signaling pathway. Mol Cell Biochem 448: 225-235, 2018.

43. Milhavet O, Gary DS and Mattson MP: RNA interference in biology and medicine. Pharmacol Rev 55: 629-648, 2003.

44. Tam C, Wong JH, Cheung R, Zuo T and Ng TB: Therapeutic potentials of short interfering RNAs. Appl Microbiol Biotechnol 101: 7091-7111, 2017.

45. Ramachandran PS, Keiser MS and Davidson BL: Recent advances in RNA interference therapeutics for CNS diseases. Neurotherapeutics 10: 473-485, 2013.

46. Corydon TJ: Antiangiogenic eye gene therapy. Hum Gene Ther 26: 525-537, 2015.

47. Moore NA, Bracha P, Hussain RM, Morral N and Ciulla TA: Gene therapy for age-related macular degeneration. Expert Opin Biol Ther 17: 1235-1244, 2017.

48. Moore SM, Skowronska-Krawczyk D and Chao DL: Emerging concepts for RNA therapeutics for inherited retinal disease. Adv Exp Med Biol 1185: 85-89, 2019.

49. Yang XM, Wang YS, Zhang J, Li Y, Xu JF, Zhu J, Zhao W, Chu DK and Wiedemann P: Role of PI3K/Akt and MEK/ERK in mediating hypoxia-induced expression of HIF-1alpha and VEGF in laser-induced rat choroidal neovascularization. Invest Ophthalmol Vis Sci 50: 1873-1879, 2009.

50. Lee CS, Choi EY, Lee SC, Koh HJ, Lee JH and Chung JH: Resveratrol inhibits hypoxia-induced vascular endothelial growth factor expression and pathological neovascularization. Yonsei Med J 56: 1678-1685, 2015.

51. Biswal MR, Prentice HM, Smith GW, Zhu P, Tong Y, Dorey CK, Lewin AS and Blanks JC: Cell-specific gene therapy driven by an optimized hypoxia-regulated vector reduces choroidal neovascularization. J Mol Med (Berl) 96: 1107-1118, 2018

52. Zhang T, Li X, Yu W, Yan Z, Zou H and He X: Overexpression of thymosin beta-10 inhibits VEGF mRNA expression, autocrine VEGF protein production, and tube formation in hypoxia-induced monkey choroid-retinal endothelial cells. Ophthalmic Res 41: 36-43, 2009.

53. Jin J, Yuan F, Shen MQ, Feng YF and He QL: Vascular endothelial growth factor regulates primate choroid-retinal endothelial cell proliferation and tube formation through PI3K/Akt and MEK/ERK dependent signaling. Mol Cell Biochem 381: 267-272, 2013.

54. Li R, Du J and Chang Y: Role of autophagy in hypoxia-induced angiogenesis of RF/6A cells in vitro. Curr Eye Res 41: 1566-1570, 2016.

55. Cui K, Zhang S, Liu X, Yan Z, Huang L, Yang X, Zhu R and Sang A: Inhibition of TBK1 reduces choroidal neovascularization in vitro and in vivo. Biochem Bioph Res Co 503: 202-208, 2018.

56. Borcar A, Menze MA, Toner M and Hand SC: Metabolic preconditioning of mammalian cells: Mimetic agents for hypoxia lack fidelity in promoting phosphorylation of pyruvate dehydrogenase. Cell Tissue Res 351: 99-106, 2013

57. Cabral T, Mello L, Lima LH, Polido J, Regatieri CV, Belfort RJ and Mahajan VB: Retinal and choroidal angiogenesis: A review of new targets. Int J Retina Vitreous 3: 31, 2017.

58. Farnoodian M, Sorenson CM and Sheibani N: Negative regulators of angiogenesis, ocular vascular homeostasis, and pathogenesis and treatment of exudative AMD. J Ophthalmic Vis Res 13: 470-486, 2018

59. Farnoodian M, Wang S, Dietz J, Nickells RW, Sorenson CM and Sheibani N: Negative regulators of angiogenesis: Important targets for treatment of exudative AMD. Clin Sci (Lond) 131: 1763-1780, 2017

60. Farnoodian M, Sorenson CM and Sheibani N: PEDF expression affects the oxidative and inflammatory state of choroidal endothelial cells. Am J Physiol Cell Physiol 314: C456-C472, 2018.

61. Housset M and Sennlaub F: Thrombospondin-1 and pathogenesis of age-related macular degeneration. J Ocul Pharmacol Ther 31: 406-412, 2015

62. Terao N, Koizumi H, Kojima K, Yamagishi T, Yamamoto Y, Yoshii K, Kitazawa K, Hiraga A, Toda M, Kinoshita S, et al: Distinct aqueous humour cytokine profiles of patients with pachychoroid neovasculopathy and neovascular age-related macular degeneration. Sci Rep 8: 10520, 2018.

63. Gehart H, Kumpf S, Ittner A and Ricci R: MAPK signalling in cellular metabolism: Stress or wellness? EMBO Rep 11: 834-840, 2010. 
64. Sun Y, Liu W, Liu T, Feng X, Yang N and Zhou H: Signaling pathway of MAPK/ERK in cell proliferation, differentiation, migration, senescence and apoptosis. J Recept Signal Transduct Res 35: 600-604, 2015.

65. Rezatabar S, Karimian A, Rameshknia V, Parsian H, Majidinia M, Kopi TA, Bishayee A, Sadeghinia A, Yousefi M, Monirialamdari M and Yousefi B: RAS/MAPK signaling functions in oxidative stress, DNA damage response and cancer progression. J Cell Physiol 234: 14951-14965, 2019.

66. Marampon F, Ciccarelli C and Zani BM: Biological rationale for targeting MEK/ERK pathways in anti-cancer therapy and to potentiate tumour responses to radiation. Int J Mol Sci 20: 2530 2019.

67. Khaliq $M$ and Fallahi-Sichani M: Epigenetic mechanisms of escape from BRAF oncogene dependency. Cancers (Basel) 11: $1480,2019$.

68. Degirmenci U, Wang $\mathrm{M}$ and $\mathrm{Hu} \mathrm{J}$ : Targeting aberrant RAS/RAF/MEK/ERK signaling for cancer therapy. Cells 9: 198, 2020.

69. Huang M, Huang B, Li G and Zeng S: Apatinib affect VEGF-mediated cell proliferation, migration, invasion via blocking VEGFR2/RAF/MEK/ERK and PI3K/AKT pathways in cholangiocarcinoma cell. BMC Gastroenterol 18: 169, 2018.

70. Yamana S, Tokiyama A, Fujita H, Terao Y, Horibe S, Sasaki N, Satomi-Kobayashi S, Hirata KI and Rikitake Y: Necl-4 enhances the PLC $\gamma$-c-Raf-MEK-ERK pathway without affecting internalization of VEGFR2. Biochem Biophys Res Commun 490 $169-175,2017$
71. Gong J, Zhou S and Yang S: Vanillic acid suppresses HIF-1a expression via inhibition of mTOR/p70S6K/4E-BP1 and Raf/MEK/ERK pathways in human colon cancer HCT116 cells. Int J Mol Sci 20: e465, 2019.

72. Pachmayr E, Treese $C$ and Stein U: Underlying mechanisms for distant metastasis-molecular biology. Visc Med 33: 11-20, 2017.

73. Zhang EY, Gao B, Shi HL, Huang LF, Yang L, Wu XJ and Wang ZT: 20(S)-protopanaxadiol enhances angiogenesis via HIF-1 $\alpha$-mediated VEGF secretion by activating p70S6 kinase and benefits wound healing in genetically diabetic mice. Exp Mol Med 49: e387, 2017.

74. Ye X, Xu G, Chang Q, Fan J, Sun Z, Qin Y and Jiang AC: ERK1/2 signaling pathways involved in VEGF release in diabetic rat retina. Invest Ophthalmol Vis Sci 51: 5226-5233, 2010.

75. Hou SY, Li YP, Wang JH, Yang SL, Wang Y, Wang Y and Kuang Y: Aquaporin-3 inhibition reduces the growth of NSCLC cells induced by hypoxia. Cell Physiol Biochem 38: 129-140, 2016.

76. Shen K, Ji L, Gong C, Ma Y, Yang L, Fan Y, Hou M and Wang Z: Notoginsenoside Ftl promotes angiogenesis via HIF- $1 \alpha$ mediated VEGF secretion and the regulation of PI3K/AKT and Raf/MEK/ERK signaling pathways. Biochem Pharmacol 84: 784-792, 2012.

This work is licensed under a Creative Commons Attribution-NonCommercial-NoDerivatives 4.0 International (CC BY-NC-ND 4.0) License. 